\title{
O cordel como um gênero do discurso presente em materiais didáticos em uma perspectiva da variação linguística
}

\author{
The cordel as a discourse genreon teaching materials
}

\author{
based on a linguistic variety
}

Vanessa Yida*

\begin{abstract}
RESUMO: Este trabalho pretende traçar um paralelo entre os estudos variacionistas e a teoria dos gêneros discursivos por meio da análise do gênero cordel trabalhado em materiais didáticos e sua relação com a valorização da variação linguística regional, a fim de atuar na eliminação de possíveis preconceitos linguísticos. Para tanto, foram analisados dois materiais didáticos de Língua Portuguesa que contemplam as práticas discursivas com o gênero discursivo cordel, a saber: i) $8^{\circ}$ ano da Coleção Tecendo Linguagens, da Editora IBEP (2012) - versão governo, aprovado no PNLD 2014; ii) 70 ano do Projeto Athos: língua portuguesa, da Editora FTD (2014) - versão mercado. A fim de nortear o trabalho, foram delineadas as seguintes perguntas de pesquisa: i) É possível observar nos materiais didáticos estudados pressupostos bakhtinianos articulados à noção de gêneros do discurso?; ii) $O$ trabalho didático com o cordel presente nos materiais didáticos focalizados apresenta ou não a valorização do dialeto da região de onde ele se origina?; iii) Como se articula didaticamente o registro linguístico empregado nos cordéis com os estudos da Sociolinguística Educacional?; iv) O trabalho didático com o gênero cordel foi abordado de forma a eliminar preconceitos linguísticos? Como instrumentos de pesquisa, foram utilizadas a pesquisa e análise do gênero cordel nos materiais didáticos aliadas à luz das teorias discursivas de Bakhtin (2006), do interacionismo sócio-discursivo de Bronckart (2003), os estudos variacionistas de Labov (2008), e na perspectiva da Socioliguística Educacional de Bagno (2007) e Bortoni-Ricardo (2013). De modo geral, foi possível observar algumas reminiscências da articulação com os pressupostos bakhtinianos em relação aos gêneros discursivos; contudo, esses materiais apresentam uma abordagem aquém da variação linguística enquanto característica constitutiva do gênero cordel.
\end{abstract}

PALAVRAS-CHAVE: Gêneros discursivos. Material Didático. Cordel. Variação linguística regional. Preconceito linguístico.

\footnotetext{
* Doutoranda em Estudos da Linguagem, pela Universidade Estadual de Londrina (UEL), participa dos projetos Atlas Linguístico do Brasil (ALiB), Tesouro do Léxico Patrimonial do Galego e Português: Brasil e Variação linguística na escola: normas (VALEN). Possui experiência na área editorial, na elaboração de materiais didáticos. Contatos: vanessayida@yahoo.com.br; vanessayida@gmail.com.
} 
ABSTRACT: This work aims to comparate the variacionist studies and the teory of discursive genders by analyse of a cordel situated on teaching materials and its relation to the valorization of regional linguistic variation, in order to eliminate linguistic prejudices. For that, they were analised two teaching materials of Portuguese Language that shows the discursive practices with the cordel discursive gender, as know: i) $8^{\text {th }}$ degree (junior high school) of Tecendo Linguagens collection, IBEP (2012) - government version, PNLD 2014; ii) 7th degree Projeto Athos: língua portuguesa, FTD (2014) - market version. In order to guide the research, they were set the following research questions: i) Is it possible to observate on teaching materials the bakhtinian's theoretical assumptions based on the discussion about discourse genders?; ii) The didactic work with the cordel on didactic materials validates the valorization of the dialect where it's from?; iii) May we compare didactaly linguistic register used on cordels to the educational Sociolinguistic theory?; iv) The didactic work with the cordel gender was studied with a form to eliminate linguistic prejudice? As research tools, it was used the research and analyses of cordel gender on the didactic materials added to the light of Bakhtin's theoretical approach (2006), to Bronckart's sociodiscursive interactionist (2003), Labov's variationist studies (2008), and Bagno's (2007) and Bortoni-Ricardo's (2013) Educational Socioliguistic. In a general view, it was possible to see some work using the Bakhtin's assumptions relative to the discursive genders; however, these materials shows a insufficient approach of the linguistic variation as a characteristic of the cordel gender.

KEYWORDS: Discursive genders. Didactic materials. Cordel. Regional Linguistic variation. Linguistic prejudice.

\section{Apontamentos iniciais}

Na obra Marxismo e filosofia da linguagem, Bakhtin (2006) critica o objetivismo abstrato e o pensamento da língua como sistema de normas rígidas e imutáveis, pois as línguas estão em contínua transformação. A língua, assim como as normas sociais, é ligada à consciência subjetiva, em dado momento histórico, em dada comunidade.

De acordo com o supracitado autor, o falante utiliza a língua com propósitos enunciativos concretos, ou seja, a língua é construída na enunciação da fala. Para o locutor, importam: o uso da forma linguística adequada ao contexto e o signo adequado à situação concreta. Segundo o estudioso, o signo é variável e flexível; o locutor deve levar em conta o receptor e precisa adaptar a forma linguística para que haja intercompreensão. 
Na prática, de acordo com a teoria bakhtiniana, a consciência linguística do locutor e receptor não está relacionada às formas normativas da língua, mas à linguagem e aos contextos de uso, por isso "[...] a palavra está sempre carregada de um conteúdo ou de um sentido ideológico ou vivencial" (BAKHTIN, 2006, p. 96). A forma linguística apresenta-se aos locutores em contexto de enunciação preciso e implica contexto ideológico - somente reagimos às palavras que despertam "ressonâncias ideológicas" ou algo sobre a vida. A enunciação, mesmo na escrita, é resposta a algo, um "elo de cadeia de atos de fala". Toda inscrição traz em si outras que a precederam, antecipa-as, trava uma polêmica com elas. Portanto, "[...] o sentido da palavra é totalmente determinado por seu contexto" (BAKHTIN, 2006, p. 107). A reflexão linguística de caráter formal sistemático não condiz com a abordagem histórica e viva da língua.

Já o subjetivismo abstrato lidava com a ideia de que a expressão era construída no interior, sendo o exterior apenas a tradução dela. Na realidade, é a expressão (exterior) que organiza a atividade mental (interior), determinada pela situação social, ou seja, a palavra dirige-se ao interlocutor (existe e varia em função dele). Assim, o horizonte social é o que determina a criação ideológica do grupo social.

O mundo interior e a reflexão de um indivíduo seguem fronteiras de uma classe e época definidas. A palavra procede de alguém e se dirige a outro; por meio dela defino-me em relação em outro (coletividade). Toda enunciação é dirigida a um auditório social.

Em Estética da criação verbal, Bakhtin (1997) comenta que os modos de utilização da língua são tão variados quanto as esferas da atividade humana e, mesmo assim, há unidade nacional da língua, atuando forças centrífugas (variação) e centrípetas (unidade) nessa variação. $O$ enunciado reflete as condições dos variados integrantes de esferas da atividade humana - pelo 
conteúdo temático e estilo verbal (recursos lexicais, fraseológicos e gramaticais) e pela construção composicional - marcando uma esfera de comunicação. Cada esfera de utilização da língua elabora tipos mais ou menos estáveis de enunciados, os gêneros do discurso. A amplitude de gêneros do discurso é tão grande quanto a quantidade de atividades humanas que se desenvolvem com elas. As forças centrífugas e centrípetas atuam no gênero, marcando traços de "relativa estabilidade", e "pontos de fuga", revelando uma dupla face (forças de concentração e forças de expansão) que compõe os gêneros, fato esse a que os professores devem se atentar, comenta Brandão (2000, p. 38).

A teoria bakhtiniana do discurso ainda trata da diferenciação do gênero do discurso primário (simples) e secundário (complexo). Os gêneros do discurso secundário (romance, teatro, discurso científico etc.), demarcam a circunstância de comunicação cultural, mais completa, escrita - artística, científica, sociopolítica (mais ideológicos). Por outro lado, são compostos por gêneros primários - a comunicação verbal espontânea (menos ideológicos). O cordel, portanto, pode ser tido como um gênero secundário. Alves (2008, p. 105) assim o classifica: "[...] gênero secundário e plurivocal, uma vez que se trata de uma manifestação artística dentro da cultura popular". Soma-se a isso, a contribuição de Severo (2011, p. 11): "[...] os gêneros vinculados às esferas literárias tendem a impor uma força normativa menor sobre as escolhas linguísticas, abrindo mais possibilidades para a criatividade linguística". Essas citações reforçam o emprego de formas populares da língua e regionalismos nesses textos.

O estilo é ligado às formas típicas do enunciado, aos gêneros do discurso. Os enunciados oral e escrito, primário e secundário, em qualquer esfera da comunicação são individuais, possuem estilo individual de quem o escreve, embora alguns gêneros não sejam tão propícios a idiossincrasias. Os gêneros mais propícios são os literários e os menos são os gêneros do discurso 
que têm forma padrão, como os documentos oficiais. Portanto, existe um vínculo entre estilo e gênero; o estilo linguístico é estilo do gênero peculiar de uma esfera da atividade humana. $O$ estilo é vinculado a unidades temáticas e a unidades composicionais - estruturação e conclusão, relação entre locutor e parceiros da comunicação verbal.

Ainda de acordo com Bakhtin (1997), as mudanças históricas de estilos da língua repercutem nos gêneros. Os fenômenos novos (fonéticos, lexicais, gramaticais) não entram no sistema sem antes serem testados no estilo gênero. A língua escrita incorpora camadas da língua popular - acarreta nos gêneros a aplicação de procedimento de modificação do todo verbal e provoca reestruturação dos gêneros do discurso. Os gêneros têm um valor normativo pois não é o falante que os cria, ele os recebe. O enunciado, embora tenha singularidade, criatividade e individualidade, não é uma combinação absolutamente livre das formas da língua.

Posto isso, conforme já enunciado anteriormente, este trabalho pretende traçar um paralelo entre os estudos variacionistas e a teoria dos gêneros discursivos por meio da análise do gênero cordel trabalhado em materiais didáticos, a fim de verificar sua relação com a valorização da variação linguística regional, de modo a minimizar possíveis preconceitos linguísticos. Para tanto, foram analisados dois materiais didáticos de Língua Portuguesa que contemplam as práticas discursivas com o gênero discursivo cordel, a saber:

i) $8^{\circ}$ ano da Coleção Tecendo Linguagens, da Editora IBEP (2012) versão governo, aprovado no PNLD 2014;

ii) 70 ano do Projeto Athos: língua portuguesa, da Editora FTD (2014) versão mercado.

A escolha dos materiais didáticos em estudo deve-se à natureza e o público-alvo dessas obras, tendo em vista que a primeira é uma versão para o 
governo e a segunda trata-se de uma versão para o mercado, apresentando visões e um sistema de avaliação diferente entre elas.

Como norteamento do trabalho, foram delineadas as seguintes perguntas de pesquisa:

i) É possível observar nos materiais didáticos estudados pressupostos bakhtinianos articulados à noção de gêneros do discurso?;

ii) O trabalho didático com o cordel presente nos materiais didáticos focalizados apresenta ou não a valorização do dialeto da região de onde ele se origina?;

iii) Como se articula didaticamente o registro linguístico empregado nos cordéis com a teoria Sociolinguística Educacional?;

iv) O trabalho didático com o gênero cordel foi abordado de forma a eliminar preconceitos linguísticos?

Como instrumentos de pesquisa, foram utilizadas a pesquisa e análise do gênero cordel nos materiais didáticos à luz das teorias discursivas de Bakhtin (2006), do interacionismo sócio-discursivo de Bronckart (2003), os estudos variacionistas de Labov (2008), e na perspectiva da Sociolinguística Educacional de Bagno (2007) e Bortoni-Ricardo (2013).

Após breve delineamento da teoria discursiva bakhtiniana, apresentada nessa seção, foram entrecruzados os pontos de convergência entre as teorias bakhtiniana e laboviana, dada a perspectiva de ambas se pautarem na interação social, sob vieses diferentes.

\section{A vinculação entre a Sociolinguística laboviana e os estudos discursivos bakhtinianos}

Bakhtin concebia a língua em contexto sociointeracionista, ou seja, na natureza dos enunciados em uso, na interação social, em perspectiva 
discursiva. Labov, por sua vez, trabalha com a ideia interacionista em contexto de uso e sua vinculação social, de modo empírico. Tanto Bakhtin quanto Labov rejeitam a ideia estática e homogênea da abordagem estruturalista de Saussure, e a perspectiva da língua em uma psique individual, desvinculada do contexto social e interacional. Para Labov, a língua é um fato social e, portanto, apresenta-se heterogênea, em constante processo de variação e mudança, por fatores sociais, estilísticos e linguísticos. A língua reflete a estrutura social, é uma obra "em construção" pelo falante; do mesmo modo, mudanças na estrutura social repercutem em mudanças na estrutura linguística.

Os estudos labovianos foram precursores do trabalho com as crenças e atitudes linguísticas, influenciando os trabalhos da Psicologia Social de Lambert e Lambert (1972) a respeito da avaliação consciente dos falantes em relação à fala do outro. A noção de valor social de determinadas variantes linguísticas é influenciada pelo desenvolvimento da consciência avaliativa nos grupos sociais. Ainda, consoante Severo (2011), a variação linguística em que ocorre escolha das variantes de acordo com a avaliação da situação de interação é a variação estilística; sob esse viés, a relação entre os interlocutores, o contexto social e o tópico são utilizados como critérios avaliativos pelo falante para escolha do estilo de uso linguístico. A variação estilística pode dar-se pelo monitoramento da fala, pois é possível dizer a mesma coisa, de acordo com a situação, que pode exigir um modo mais ou menos formal, conforme a formalidade/informalidade do contexto de interação. Tal expressividade está ligada ao valor social que é dado ao uso de determinadas variantes linguísticas em detrimento de outras, ou, de acordo com Bakhtin, a relação que os sujeitos estabelecem com o objeto do discurso. Correlacionando Labov e Bakhtin, a variação do estilo é afetada pela percepção que locutor tem de seu destinatário: 
A quem se dirige o enunciado? Como o locutor (ou o escritor) percebe e imagina seu destinatário? Qual é a força da influência deste sobre o enunciado? É disso que depende a composição, e sobretudo o estilo, do enunciado. Cada um dos gêneros do discurso, em cada uma das áreas da comunicação verbal, tem sua concepção padrão do destinatário que o determina como gênero (BAKHTIN, 2006, p. 321).

Ou seja, o locutor, ao perceber e imaginar o seu destinatário, adapta sua escolha do gênero a ser empregado, bem como o de seu estilo. Segundo a perspectiva da Sociolinguística, ampliada pela Sociolinguística Educacional, os estilos podem variar em um continuum do mais para o menos formal (BORTONI RICARDO, 2004), e tal aspecto influencia diretamente os usos dos gêneros, bem como a forma de registro (estilo) linguístico.

\section{Heteroglossia}

Machado (2005, p. 161) destrincha o conceito de cronotopo de Bakhtin, e afirma que para se compreender um sistema cultural é preciso observá-lo com olhar extraposto. Um observador compreende a cultura alheia colocandose em ponto de vista exterior a ela, [...] uma linguagem é sempre uma imagem criada pelo ponto de vista de outra linguagem. É por esse viés que se pode falar em heteroglossia e, consequentemente, em dialogia de linguagens".

Brait (1999) comenta que o conceito de linguagem em Bakhtin teve influência em sua juventude em Vilno, por meio do contato pessoal com várias culturas. Essa experiência o auxiliou a conceber na linguagem os conceitos de heteroglossia e pluralismo linguístico. Segundo a autora, trata-se da mistura de línguas, culturas e classes, que se traduzem com a concepção de variação como realidade da língua e o confronto entre língua e cultura no mesmo espaço geográfico. A autora ainda salienta que os conceitos de heteroglossia e plurilinguismo explorados por Bakhtin são também admitidos nos estudos sociolinguísticos: 
[...] conceito de heteroglossia, plurilinguismo [...] tanto tem a ver com a variação linguística, no sentido assumido, desenvolvido e explorado por várias correntes da Sociolinguística, quanto com os conceitos de intertextualidade, interdiscursividade, interdiscurso, heterogeneidade, dimensões acenadas por Bakhtin como sendo constitutivas da linguagem. [...] (BRAIT, 1999, p. 26).

A autora ainda explica que nos estudos de Bakhtin seria empobrecedor restringir o conceito de heteroglossia a apenas estudos sociolinguísticos ou somente à polifonia do romance. Expressões como hetero, pluri, inter, intra são da natureza constitutiva da linguagem, componente real da língua e, por conseguinte, dos sujeitos e sentidos.

Faraco e Negri (1998), por sua vez, comentam sobre o olhar a respeito da língua segundo práticas discursivas, e a realidade linguística que a configura sempre como heteroglótica (plurilíngue, pluridiscursiva, pluriestilística), permeada por vozes sociais em que entrelaçam palavras e valores, que põem a realidade linguística em constante movimento. Para além do conceito de heteroglossia, trabalhado também na Sociolinguística e na Dialetologia, explorados por Chambers e Trudgill (1994), que reconhecem e demarcam os dialetos e a variação linguística de modo descritivo, a perspectiva da heteroglossia dialógica aprofunda a visão dessa diversidade linguística, como um embate de valores.

O trabalho com os regionalismos no cordel revela a pluralidade linguística e cultural brasileira na medida em que a região Nordeste é um celeiro étnico de multiplicidades. Desse modo, essa abordagem da variação linguística regional dá voz ao povo.

No trecho a seguir, foram discutidas a noção de competência comunicativa e a questão do preconceito linguístico na educação linguística.

\section{A competência comunicativa e a eliminação do preconceito linguístico na educação linguística}


A educação linguística, no contexto atual, deve dar conta de múltiplos letramentos para instrumentalizar 0 aluno a atuar nesse mundo multissemiótico, salientam Moita Lopes e Rojo (apud ROJO, 2008). A educação linguística, desse modo, configura-se como fundamental para formar o cidadão, sendo o papel do discurso, em sociedades densamente semiotizadas, auxiliá-lo a proceder escolhas éticas. Para tanto, é preciso que o aluno entenda como a linguagem funciona e como ela se relaciona com a construção da cidadania, por meio de práticas didáticas multimodais que os gêneros possibilitam.

O papel do professor, portanto, é o de mediador intermediário do conhecimento ao aluno que, por meio do instrumento material didático e o estudo dos gêneros, o coloca a par desse contexto multissemiótico.

O gênero, como prática discursiva, é um instrumento semiótico e, ao internalizá-lo, os alunos adquirem capacidade de agir comunicativo, em variadas situações sociais do cotidiano. Nascimento (2015) comenta que os gêneros verbais e não verbais são empregados em práticas discursivas de diversas esferas sociais.

É importante que os alunos tenham contato com variados gêneros do discurso para ampliar sua competência comunicativa, pois ao comunicarem-se realizam essa ação por meio de gêneros discursivos. Ainda seguindo 0 pressuposto interacionista da linguagem, reforça Brandão (2000):

[...] ensinar a língua é desenvolver a competência comunicativa do educando e, considerando o texto uma unidade de comunicação, para nós, o aluno deve ser exposto a diferentes tipos de textos e de gêneros discursivos para apreender o que os caracteriza em suas especificidades e naquilo que os identifica (BRANDÃO, 2000, p. 40).

Para ampliar a competência comunicativa, os discentes também devem estar cientes da variação linguística e como devem moldar os gêneros utilizados em suas interações à situação comunicativa. A respeito da importância de o 
ensino escolar, mediado pelo professor, atuar como um instrumento para reconhecimento dos papéis sociais dos alunos, Bortoni-Ricardo (2013) explica:

Em cada situação, em cada evento ou ato de fala, os interagentes têm expectativas culturalmente definidas sobre o que falar e como falar. Daí a responsabilidade da escola ao trabalhar com a pedagogia linguística. Aos alunos não se podem sonegar os recursos linguísticos que os vão habilitar a modular sua fala (e sua escrita) conforme o que se espera deles, em qualquer papel social que tenham de desempenhar.

Aprender na escola que existem modos diferentes de falar, que podemos ajustar de acordo com as circunstâncias, é um passo importante na formação de nossos jovens. Por isso entendemos que a contribuição da Sociolinguística é crucial na formação dos professores e nos currículos escolares nas escolas brasileiras (BORTONI-RICARDO, 2013, p. 53-54).

Pode-se inferir, após a leitura da assertiva da sociolinguista, que é preciso que os alunos reconheçam que há várias formas de lidar com a linguagem, e que a formulação da comunicação emerge do contexto social, interativo.

De acordo com os Parâmetros Curriculares Nacionais do Ensino Fundamental de Língua Portuguesa, de terceiro e quarto ciclos (BRASIL, 1998), é proposto que a linguagem na escola torne-se objeto de reflexão e análise, permitindo ao aluno o exame de seus significados implícitos e explícitos. Todo o conhecimento deve vincular-se à experiência já construída, estabelecendo relações com o conhecimento instituído por meio do contato com a sociedade. O aluno deve reconhecer os diversos conhecimentos e opiniões sobre as manifestações da linguagem, respeitando-as como construções simbólicas da diversidade histórica, social e cultural. Desse modo, a escola deve atuar como ambiente para uma mudança de atitudes e combate à discriminação linguística, não rotulando as variedades linguísticas como desvio ou incorreção, dada a gama de variação de usos e de situações. Além disso, existem os padrões utilizados na escrita e os de uso oral, mesmo que haja situações orientadas 
pela escrita. Continuam os PCN, quanto ao preconceito linguístico e o combate a ele que a escola deve exercer:

A discriminação de algumas variedades lingüísticas, tratadas de modo preconceituoso e anticientífico, expressa os próprios conflitos existentes no interior da sociedade. Por isso mesmo, o preconceito lingüístico, como qualquer outro preconceito, resulta de avaliações subjetivas dos grupos sociais e deve ser combatido com vigor e energia. É importante que 0 aluno, ao aprender novas formas lingüísticas, particularmente a escrita e o padrão de oralidade mais formal orientado pela tradição gramatical, entenda que todas as variedades lingüísticas são legítimas e próprias da história e da cultura humana.

Para isso, o estudo da variação cumpre papel fundamental na formação da consciência lingüística e no desenvolvimento da competência discursiva do aluno, devendo estar sistematicamente presente nas atividades de Língua Portuguesa (BRASIL, 1998, p. 82).

O ensino de língua portuguesa nas escolas, pautado exclusivamente na imposição da norma urbana de prestígio, reforça a ideologia repressora da cultura enquanto única, padronizada e tonifica a noção da língua como instrumento de domínio social. A hierarquização da sociedade incute a ideia de valores culturais e avaliações sociais, e a língua acaba sendo vista como um instrumento de nivelamento e embate de forças sociais.

Como explica Bagno (2007), é preciso uma reeducação sociolinguística, sem a ideia de correção ou da incorreção e substituição de um tipo de falar em face de outro; deve partir do que o aluno já sabe, que é falar a língua materna. Para tanto, ele deve estar ciente dos juízos de valor sobre os usos da língua. 0 autor ainda elenca outras mudanças de atitudes no ensino da língua, como promover a autoestima linguística dos alunos, fazendo-os reconhecer que já sabem o português, e que devem desenvolver ainda mais o que já conhecem; auxiliá-los a reconhecer os valores sociais incutidos nos usos de fala, sem aceitar esse tipo de situação, nem promover tal ideologia; os professores devem ainda aplicar métodos a fim de ampliar o repertório comunicativo dos 
discentes quanto a outras formas de se comunicar (variados gêneros), destruindo possíveis preconceitos linguísticos; os docentes precisam demonstrar aos alunos, por meio de práticas de letramento, os gêneros textuais que atuam na sociedade, e a variação de grau de monitoramento, de modo a promover o reconhecimento da diversidade linguística, como parte da nossa língua e de nossa cultura.

A seguir, foram apresentadas as características configuracionais do cordel, gênero textual que dá voz à diversidade linguística.

\section{0 gênero cordel}

O cordel é um gênero que possui como característica o uso de formas linguísticas típicas de determinadas regiões (principalmente as do Nordeste). Evaristo (2000) comenta que esse gênero compõe-se praticamente de uma transposição da fala oral para a escrita, intermediário entre cultura popular e a escrita, caracterizando-se também por possuir função social educativa, abordando temas do cotidiano. Em relação à dialogicidade, o sujeito-narrador desses textos dialoga com o que já foi produzido, reelabora histórias com sua visão de mundo. A supracitada autora ainda classifica o cordel como uma modalidade discursiva narrativa de caráter popular, de tradição originalmente oral, com formas simples, enraizadas na vivência, tipicamente brasileira. De fato, de acordo com Bakhtin (2006), cada época, nas esferas da vida, as tradições se expressam por meio das palavras e, no caso do cordel, por meio das formas linguísticas relacionadas ao falar nordestino e regionalismos.

Os novos mecanismos de mediatização dos cordéis, como o uso do computador para confeç̧ão das capas, que geralmente eram impressas como xilogravuras, não descaracterizaram o gênero, que tem se transformado, aliado à sociedade (esse fato reforça o pressuposto bakhtiniano da teoria dos gêneros - um todo relativamente estável). Embora tradicionalmente a literatura de 
cordel esteja relacionada ao Nordeste, com as migrações, é possível encontrar esses folhetos também no Rio de Janeiro e em São Paulo. Os textos produzidos misturam elementos eruditos e histórias do sertão nordestino.

Alguns atributos do cordel mencionados por Evaristo (2000) são as marcas formais: sextilhas, setessilábicas, quadras e poemas de dez versos. Outra característica do gênero elencada pela autora são as marcas de linguagem popular falada, que se manifestam no uso lexical (regionalismos), sintaxe, prosódia e "desvios" ortográficos da norma padrão.

Após a contextualização das características gerais do gênero cordel, procedeu-se à análise dos corpora.

\section{Análise dos corpora - o gênero cordel nos materiais didáticos}

Desde os anos 1980, têm sido operadas mudanças na relação ensino e aprendizagem da língua, centrando o trabalho com os textos em sua dimensão textual e discursiva, segundo a concepção sócio-interacionista da linguagem.

Cada texto possui uma forma de abordagem da interação diferente, com diferentes formas de textualização, propendendo à situação de interlocução, culminando na noção de gêneros, esclarece Brandão (2000).

O trabalho com o gênero cordel nos materiais didáticos visa instrumentalizar o aluno na capacidade de reconhecer tal texto, e suas características enquanto narrativa, bem como a sua particularidade de retextualização (texto oral passado para o escrito).

A seguir, foram elencadas as análises com os materiais didáticos de Língua Portuguesa: Projeto Athos (2014) e Coleção Tecendo Linguagens (PNLD 2014). O objetivo é verificar se estão sendo aplicados os pressupostos teóricos discursivo sócio-interacionistas e variacionistas em dois materiais com públicosalvo diferentes (mercado e governo, respectivamente). 


\section{Análise do material Projeto Athos: Língua portuguesa, $7^{\circ}$ ano (2014), versão mercado, Editora FTD}

O material do Projeto Athos (2014), da editora FTD, para o 70 ano (versão mercado) - doravante PA - apresenta a perspectiva téorica interacionista discursiva alicerçada em Bakhtin (2007) expressa explicitamente em seu manual.

Dentre as habilidades a serem desenvolvidas pelos alunos em relação ao trabalho com o gênero cordel, o material arrola no Manual do Professor (em formato de $U$, na parte específica do material didático), o reconhecimento de características textuais e discursivas que o compõem; identificação do contexto de produção e recepção, e a reflexão sobre o gênero, para identificar sua finalidade e como a informação é tratada em uma situação de comunicação.

O PA inicia sua atividade com o texto por meio de um texto informativo a respeito do gênero, versando sobre uma das características principais da gênese do cordel, que passou da linguagem oral para a escrita (retextualização), estimulando a reflexão sobre a importância desses textos para contribuição da preservação de tradições locais, além de trazer uma questão para que o aluno reflita sobre o conhecimento próximo - se é possível que os cordéis retratem as tradições de um local. Desse modo, o professor pode fazer uma avaliação diagnóstica do que o discente conhece sobre 0 gênero em questão e se eles reconhecem o vínculo desses textos com a manutenção de tradições.

Logo após, na mesma página, é apresentado outro boxe informativo a respeito das xilogravuras presentes nas capas dos cordéis, contextualizando a técnica. Há ainda a reprodução de duas capas de folhetos de cordel, para que os alunos as analisem, observando os títulos e realizando, por meio da interpretação das imagens, uma leitura prévia e o levantamento de hipóteses sobre o que provavelmente será tratado nesses cordéis. 
Após essa prévia, o material PA apresenta o cordel "A festa da natureza", de autoria de Patativa do Assaré, um dos maiores poetas e cordelistas cearense. No manual específico, os autores do livro didático recomendam que os alunos façam uma leitura silenciosa e o professor proponha uma discussão sobre as características do gênero, as marcas de oralidade, e iniciem uma reflexão sobre os contextos de produção e recepção do cordel e suas características estruturais. Apresenta ainda um boxe sobre 0 autor e algumas questões sobre o tema tratado no cordel. Os autores situam esse tema (estado do Ceará, terra natal do cordelista), solicitando aos alunos que pressuponham sobre quais aspectos o texto vai tratar, instigando o levantamento de hipóteses e a interpretação do título e a sua correlação com a visão do poeta. O trabalho com o contexto de produção é simplesmente salientado no Manual, sem uma indicação de como realizá-lo. Bronckart (2003) analisa as condições de produção dos textos, alicerçando sua teoria em Bakhtin, em um viés interacionista sócio-discursivo (doravante ISD). Segundo sua concepção teórica, o contexto de produção exerce influência na forma de organização do texto, sob o conjunto de dois fatores: mundo físico ou social e mundo subjetivo. Segundo critério do mundo físico, o texto resulta de comportamento verbal concreto, situado em tempo e espaço (ato realizado no contexto físico) e é definido por:

a) Lugar de produção: lugar físico de produção do texto;

b) Momento de produção: extensão do tempo durante o qual texto é produzido;

c) Emissor (produtor ou locutor): quem produz fisicamente o texto (modalidade oral ou escrita);

d) Receptor: quem pode perceber concretamente o texto. 
O Manual da obra deveria, portanto, indicar questões de modo a auxiliar o professor a direcionar a reflexão dos alunos em relação ao contexto de produção do texto, seguindo esses parâmetros do ISD.

$\mathrm{Na}$ página 93, são apresentadas mais questões sobre o gênero, pretendendo instigar a discussão sobre o contexto e os sentidos do texto. Os alunos são levados, por exemplo, a correlacionar alguns títulos de cordéis aos temas elencados pelos autores, de modo mecânico, sem indicar alguma reflexão sobre a atividade, apenas buscando tratar de uma característica desses textos (relação entre título e tema). Em outra pergunta sobre o título, é solicitado aos alunos imaginarem como a região Nordeste está presente nos títulos dos cordéis, para que a correlacionem com os nomes de personagens e fatos históricos nordestinos, articulando o conteúdo temático, mas sem correlacioná-lo explicitamente com o contexto de produção.

$\mathrm{Na}$ atividade a respeito dos sentidos do texto, os autores optaram pela escolha da análise do significado de uma expressão (festa), contudo, não se trata de um item lexical que caracteriza o cordel e, por isso, não auxilia a instrumentalizar o aluno no reconhecimento do gênero. Em outra questão (na página 94), há uma pergunta sobre o uso dos adjetivos em um trecho descritivo do cordel, atividade que seria uma boa oportunidade para levar os alunos a refletir sobre a presença de sequências descritivas em textos narrativos.

De acordo com Bronckart (2003), os tipos de discursos constituem elementos fundamentais da infraestrutura geral dos textos, a qual também se caracteriza pela organização sequencial do conteúdo temático. Nela, são organizadas as camadas dos tipos de discursos que o constituem. O cordel, desse modo, organiza-se no eixo do NARRAR, em disjunção com as coordenadas gerais do mundo ordinário. Entretanto, nos textos, é possível 
observar, além de sequências narrativas, as sequências descritivas, como no caso desse exemplo de cordel.

No trecho que explora o estudo do texto (página 95), denominado "A construção do gênero", a primeira questão diz respeito à composição dos cordéis em rimas e estrofes e apresenta um boxe com a explanação de que o cordel possui número fixo de versos com rimas que se repetem em mesma posição e estrofes também fixas (sextilha, oitava e décima). A seguir, em outra atividade, é proposto ao aluno que faça uma escansão poética. No Manual específico, é sugerido ao professor que realize um debate com os alunos sobre a importância da divulgação de culturas populares.

Para finalizar a atividade com as rimas, os autores apresentam um boxe explicando que a forma de composição do cordel (em rimas, com número fixo de versos e estrofes) facilita a memorização para a posterior recitação pelos cordelistas.

Logo após (página 96), outra questão aborda o caráter da oralidade presente nesse gênero, sem abordar a questão da variação linguística e a presença de regionalismos, traço marcante do gênero. Apenas pede-se ao discente que correlacione trechos do texto com as formas em que foram "grafadas" com as supressões de vogais no final de sílabas, monotongações e os desvios de concordância nominal da norma padrão, características da fala os quais são classificados como traços graduais por Bortoni Ricardo (2004), pois não suscitam uma avaliação negativa pelo ouvinte, dada a inserção desses usos ser bem difundida em vários domínios sociais. Ao final da atividade, é apresentado um boxe explicativo sobre as marcas de oralidade presentes no cordel, comentando sobre a sua origem oral, e a passagem do texto para o registro escrito. Ao final da página, os autores propõem uma atividade de comparação entre a poesia (que foi trabalhada anteriormente, em outro capítulo) e o cordel; as diferenças na composição dos textos. 
A atividade mecânica, desenvolvida no material, somente de localização no cordel das marcas de oralidade não propicia aos alunos a reflexão sobre a variação linguística regional, como forma de valorização linguística e consequente eliminação do preconceito linguístico quanto às marcas de oralidade presentes no texto.

Os autores da coleção PA ainda apresentam uma atividade suplementar (no Manual específico) com a utilização de um cordel para explorar os usos dos porquês - "A gramática no cordel", de Janduhi Dantas, relacionando a explicação à teoria discursiva de Bakhtin (1995) - os textos são produzidos com uma finalidade, sem contudo, mencionar o público-alvo - traço relevante ao se conceber interagir por meio de um gênero discursivo (todo enunciado possui um auditório social estabelecido). Portanto, a atividade é dada apenas como um pretexto para o trabalho com um aspecto gramatical.

Já na atividade subsequente, na página 97, ainda comparando o cordel com o poema, o aluno é questionado sobre a esfera de circulação e o público a que se dirige cada gênero (auditório social). Desse modo, os autores do material salientam a circulação do gênero cordel originalmente em feiras e como um gênero oral. São explorados ainda a temática do cordel em relação à da poesia (assuntos mais próximos ao leitor no cordel, enquanto no poema tudo pode servir como tema) e quais são os registros da língua utilizados em cada texto (formal ou informal): nas respostas, os autores consideram o poema como registro formal, retratando a visão de um eu lírico provavelmente de classe alta e escolarizado e no cordel, informal, uma visão de um eu lírico de classe mais baixa e menos escolarizado. Dessa maneira, os autores equivocadamente relacionam o registro formal ao emprego realizado por indivíduos oriundos de classes mais escolarizadas em contraponto ao registro informal, apontando-o como um uso de falantes com escolaridade inferior, reforçando o preconceito linguístico. Bagno (2015, p. 64) enumera esse senso 
comum como "mito número 4: as pessoas sem instrução falam tudo errado", e explica que o preconceito linguístico, em seu âmago, volta-se principalmente à posição social do falante, ao desprestígio social que envolve o falante que produz as formas linguísticas consideradas "pobres", "feias" ou "vícios de linguagem".

Ademais, é consabido na literatura referente à Sociolinguística Educacional, conforme salientam Martins, Vieira e Tavares (2014, p. 13-14), que:

Embora seja verdadeira a concepção de que os modelos de normapadrão se estabeleçam a partir do que idealizado em registro formal, não é igualmente verdadeira a correlação, no que se refere ao plano dos usos linguísticos, entre normas cultas e registros formais, ou entre normas populares e registros informais.

Os alunos devem ter em mente que falantes de vários níveis de escolaridade podem comunicar-se segundo variados níveis de formalidade, fator esse que diz respeito à competência comunicativa.

No final da página, é proposta uma atividade oral, na seção denominada "Interação", para leitura das estrofes em voz alta pelos alunos a fim de que eles percebam o ritmo empreendido pelas rimas no cordel "Romance do pavão misterioso", de João Melquíades Ferreira.

\section{Análise do material didático Coleção Tecendo Linguagens, $8^{\circ}$ ano, versão governo) - PNLD 2014 - Editora IBEP}

Os autores do material Língua Portuguesa, Coleção Tecendo Linguagens, doravante $T L$, iniciam a atividade com o gênero apresentando a capa do cordel "Galopando o cavalo pensamento", de Marco Haurélio (na página 60), asseverando que o cordel tem origem na tradição oral. Algumas perguntas intentam levantar os conhecimentos prévios dos discentes a respeito do gênero, para que comentem sobre o que sabem a respeito dele. Além disso, é 
resgatada com os alunos uma pesquisa solicitada anteriormente sobre 0 cordelista Patativa do Assaré.

Na página seguinte, foi apresentado o poema de cordel "O poeta da roça", de Patativa do Assaré. Nas questões sobre o texto (página 62), foi sugerido aos alunos que falem sobre o autor do cordel, e no Manual são trazidas informações biográficas sobre ele, para que o professor possa informar os discentes. Logo após, é questionado sobre o que mais chama atenção no poema, e qual foi o ambiente que inspirou o poeta a escrevê-lo. Essa última pergunta poderia ensejar a reflexão sobre o contexto de produção, mas configura-se apenas como uma interpretação textual e de localização.

A próxima questão refere-se ao léxico empregado no poema de cordel, para que os alunos façam um agrupamento semântico de expressões ligadas à roça. As três últimas questões referem-se ao eu poético: se ele faz parte da roça, qual é a atividade profissional dele e uma atividade mecânica de cópia de uma frase que define as atitudes do eu lírico. Tratam-se de atividades mecânicas de interpretação de texto, sem reflexão e sem estabelecer vínculo com o gênero.

Na próxima página (63), as seis primeiras questões também estimulam mais a interpretação textual, além da localização de informações no cordel e atividades automáticas. Logo após, os autores propõem a interpretação das estrofes finais do poema de cordel, por meio da confecção de cartazes com frases ou ilustrações que remetam à estrofe, utilizando um registro mais formal, por tratar-se de uma exposição pública. A atividade pode ser desastrosa, pois como não há indicação de maiores explanações aos docentes, inexiste uma finalidade clara, e pode levar os alunos a associar a exposição pública e escrita ao contexto formal, fazendo-os concluir que o registro presente nos cordéis está "errado", ao propor uma atividade de transposição de norma. 
$\mathrm{Na}$ página 64, foram destacadas duas estrofes para que os alunos interpretem a relação semântica entre expressões contidas nelas e novamente uma questão de interpretação textual. Na seção "Na trilha da oralidade", a primeira questão trata de expressões que foram usadas no poema de cordel com uma forma diferente da forma padrão, para que os alunos as comparem e percebam a ausência do -r final nos verbos (assiná/estudá). Na outra atividade, é solicitado o mesmo com relação a dois substantivos (corage/visage, que também sofreram apócope de consoante final). Na terceira atividade, o aluno é levado a comparar essas expressões em um quadro - as formas de registro da norma urbana de prestígio e a variante que é usada no poema, para que percebam a regularidade que ocorre na variação linguística (queda da consoante final (-r) em verbos no infinitivo e em substantivos terminados em m) e também verifiquem, na última questão que as duplas assiná/estudá e corage/visage no final dos versos permitem a formação de rimas. A regularidade das formas que variam linguisticamente tem início nos estudos labovianos, pois mesmo na heterogeneidade da língua há uniformidade de ocorrências, daí advém a possibilidade de empreender os estudos variacionistas, dada a sua sistematicidade. No entanto, a atividade não leva os alunos à reflexão acerca dessa importância da regularidade no fenômeno da variação linguística e não a correlaciona às marcas de uso, ao caráter oral e à tentativa de ilustrá-lo, por meio da retextualização, características do gênero cordel.

A tabela utilizada pelos autores para ilustrar as diferenças grafemáticas entre o "registro convencional", tido como a norma urbana de prestígio e o "registro usado no poema" poderia também ter sido explorada, visando combater o preconceito linguístico, luta essa preconizada por Bagno (2007), elencada também como objetivo a ser atingido nos PCN. Posta dessa forma, pode levar os alunos a concluir que as formas linguísticas que se desviem da 
forma "padrão" da língua são errôneas, enquanto a finalidade dos cordéis é retratar e realçar a cultura regional, não a deturpar.

Em um boxe explicativo, na página 65 , os autores da coleção TL comentam sobre a variação linguística geográfica (variação diatópica horizontal) e a variação linguística social, vertical, sem esmiuçar uma discussão sobre a relação do fenômeno da variação linguística presente no gênero cordel, tornando-se uma informação simplesmente "jogada", desvinculada das atividades com o texto. No final da página, é apresentado outro boxe com informações a respeito da origem da literatura de cordel, desde seu surgimento na Europa até sua instalação no Brasil e sua relação com a região Nordeste.

Na página 66, inicia-se uma seção denominada "Prática de leitura", em que os autores expõem um cordel com estruturação diferente, em forma de diálogo, sem divisão em estrofes, intitulado "Guriatã: um cordel para menino", de Marcus Accioly, com algumas palavras destacadas. Logo após, propõem uma atividade para que os alunos procurem o significado das expressões grifadas no texto em dicionários e sobre quais brincadeiras são mencionadas no cordel (página 67). Tal exemplo de cordel foge à estrutura tradicional em versos, e aprimora o universo discursivo dos discentes em relação ao gênero.

As questões elencadas na página 68 levam o aluno a realizar uma interpretação do poema de cordel, quanto à situação de encantamento, a presença de elementos da natureza e ligados à cultura e os sentidos do texto (reflexão sobre metáforas).

Na última página com o trabalho sobre o cordel (página 69), há um boxe informativo sobre o contexto de produção do texto, o tempo histórico-social do Nordeste que é retratado como árido, e que se modifica aos poucos mas ainda mantém muitas lendas e mitos. Nas questões após o boxe, não são exploradas essas informações, mas sim, como é retratado o espaço no poema de cordel e é solicitado que os alunos transcrevam um trecho demonstrando a passagem 
do real para o imaginário, uma atividade meramente interpretativa, sem levar o discente a refletir sobre o contexto de produção do gênero. No final da página foram retomadas algumas características de textos poéticos estudados na Unidade e, na página 70, é proposta aos alunos a representação teatral do poema de cordel de Marcus Accioly.

\section{Considerações finais}

Os alunos, ao internalizar os gêneros (instrumentos semióticos) enquanto prática discursiva, adquirem capacidade de agir comunicativo em variadas situações sociais do cotidiano. No caso do cordel, é preciso que a transposição didática da prática discursiva, passando do campo do saber científico ao saber escolar, seja contextualizada, em seu uso coletivo e social.

As perguntas da pesquisa, arroladas no início do presente trabalho guiaram as análises dos corpora e, desse modo, conclui-se, de modo geral, que:

i) É possível observar no material didático PA (para o mercado) algumas reminiscências dos pressupostos bakhtinianos articulados à noção de gêneros do discurso, embora o material TL tenha sido, hipoteticamente, avaliado com maior rigor, pois foi aprovado no PNLD 2014. Contudo, o trabalho com o cordel enquanto prática discursiva é visivelmente mais aquém no livro didático voltado às escolas públicas;

ii) Os materiais didáticos não mencionam especificamente a valorização do dialeto da região Nordeste, por isso, sua contribuição nesse sentido é nula;

iii) Os dois livros analisados apresentam atividades que demonstram a oralidade presente nos cordéis, mas que não são suficientes 
para a instrumentalização do aluno a respeito desse gênero discursivo, ao não aprofundarem o trabalho com as marcas de oralidade presentes nos textos;

iv) Devido ao trabalho didático insuficiente com a característica da retextualização do texto oral para o texto escrito, realçada pelas marcas de oralidade, somada ainda à vinculação do registro informal à fala de pessoas com menor nível de escolaridade, a abordagem do preconceito linguístico também ficou prejudicada.

De modo específico, o material PA oferece um trabalho mais conciso com o gênero cordel e suas características, intentando resgatar os conhecimentos prévios e conhecimento próximo dos alunos a respeito desses textos, por meio de uma avaliação diagnóstica daquilo que eles já conhecem. Entretanto, o material apenas recomenda ao professor que desenvolva um trabalho com os alunos a respeito do contexto de produção do cordel, sem, contudo, indicar meios para realizá-lo. Foram abordadas as características da oralidade presentes no gênero, de modo mecânico, sem correlacioná-las à variação linguística, nem levar os alunos a refletir sobre o preconceito linguístico. Há a presença de atividades como pretexto e apenas nas atividades de comparação do cordel com o poema são trabalhados a esfera de circulação do texto e o público a que se dirige, a temática e o registro linguístico empregado nos textos. Na contramão dos estudos da Sociolinguística Educacional, a obra, ao levar o aluno a concluir que o registro formal é empregado por classes mais escolarizadas e o informal é utilizado por falantes de classes menos escolarizadas, incita o preconceito linguístico e "[...] nega a autonomia de cada contínuo de variação, que caracteriza a complexidade realidade sociolinguística brasileira" (MARTINS; VIEIRA; TAVARES, 2014, p. 14). 
O material TL apresenta, em sua maioria, atividades de interpretação textual e de localização, sem vinculá-los ao gênero, por isso, não ensejam a reflexão e não instrumentalizam o educando enquanto usuário da língua. 0 livro didático ainda destacou uma atividade que pode levar os discentes a concluir erroneamente que a exposição pública e escrita deva ser efetivada em registro formal, pelo fato de a atividade estar desvinculada do gênero cordel. Esse gênero, em geral, apresenta marcas de oralidade que constituem um traço gradual e formas linguísticas de traço descontínuo (BORTONI RICARDO, 2004), sendo as últimas, em um consenso comum, taxadas como esterótipos que demarcam a fala/escrita de pessoas menos escolarizadas ou vinculadas a um registro informal. Os estudos na área da Sociolinguística Educacional, contudo, têm demonstrado que alguns traços, tais como a monotongação ("peixe"> "pexe"), a queda da consoante $-r$ final em verbos no infinitivo ("cantar">"cantá"), configuram-se traços contínuos, empregados tanto por falantes de uma variedade popular, como por falantes tidos como "cultos de áreas urbanas", conforme salientam (BORTONI-RICARDO; ROCHA, 2014), portanto, não estão estritamente ligados ao uso de uma dada classe social ou um tipo de registro, visto que são fenômenos produtivos de modo geral no português brasileiro.

Outra pergunta da obra em pauta auxilia os alunos a perceberem a sistematicidade que ocorre na variação linguística, sem, contudo, correlacionar essas formas linguísticas ao gênero cordel. É apresentado um boxe informativo sobre a variação linguística geográfica e social, sem vinculá-las ao texto analisado. São explorados mais elementos sobre o contexto de produção e o tempo histórico-social do Nordeste, mas novamente, não são articuladas algumas atividades a essas informações, que acabam ficando "soltas".

A prática de um olhar extraposto instrumentaliza o aluno, enquanto usuário da língua, na percepção da pluralidade linguística e subsidia sua 
observação de uma cultura em relação a outra, auxiliando-o no reconhecimento, por conseguinte, da heteroglossia constitutiva da linguagem.

A educação linguística deve instrumentalizar o aluno a atuar no mundo multissemiótico, ampliando sua competência comunicativa com relação ao fenômeno da variação linguística e sua vinculação aos variados gêneros discursivos, bem como à dinamicidade dos textos, a dinâmica das relações sociais, contribuindo também para eliminação do preconceito linguístico.

Por tratar-se de um gênero secundário literário, o cordel possui uma abertura maior para a variação em seu estilo, ficando ao sabor de idiossincrasias operadas pelo autor do texto. Tal estilo deve levar em conta o receptor do gênero, o auditório social ao qual ele se dirige; portanto, ao utilizar um texto que apresenta marcas de oralidade, além de compor uma característica do gênero, infere-se que o autor considera que o interlocutor consiga reconhecê-lo como tal. A exploração de tais características do gênero ficou aquém do que se espera para a mediação da instrumentalização do discente em relação ao cordel.

Ficam lacunas a serem preenchidas a respeito do contexto de produção dos textos, pois há apenas uma recomendação para que os professores trabalhem com o contexto de produção do cordel, sem a indicação de meios como executá-lo. As atividades são muito mecânicas, não ensejam uma reflexão acerca das características temáticas do cordel.

As questões, em sua maioria, ora configuram-se como pretexto ao estudo gramatical, ora são mecânicas, de mera interpretação textual e de localização de informações no texto. Assim sendo, não cumprem com a função principal de incrementar a competência comunicativa do aluno em relação ao gênero discursivo em pauta.

Ao atuar como um "termômetro" de novos fenômenos (fonéticos, lexicais, gramaticais), o estilo-gênero auxilia na fixação das novas formas 
linguísticas geradas pela língua popular, divulgada por meio do cordel, um gênero rico em expressões regionais. Desse modo, os registros e as variantes regionais utilizadas nesses textos marcam a individualidade e o contexto interiorano do nordestino, com seus temas agrestes e suas expressões que retratam fielmente a singularidade do falar, com suas formas linguísticas que fogem a gramáticas e dicionários, mas que revelam a vivacidade da língua.

\section{REFERÊNCIAS}

ALVES, Roberta Monteiro. Literatura de cordel: por que e para que trabalhar em sala de aula. Revista Fórum identidades, Aracajú, Ano 2, v. 4, p. 103-109, juldez. 2008.

BAGNO, Marcos. Preconceito linguístico. 56. ed. São Paulo: Parábola Editorial, 2015.

BAGNO, Marcos. Nada na língua é por acaso: por uma pedagogia da variação linguística. São Paulo: Parábola Editorial, 2007.

BAKHTIN, Mikhail (VOLOCHÍNOV, V.N.). Língua, fala e enunciação. In: Marxismo e filosofia da linguagem. 12. ed. HUCITEC, 2006. p. 91-111.

BAKHTIN, Mikhail (VOLOCHÍNOV, V.N.). A interação verbal. In:

Marxismo e filosofia da linguagem. 12. ed. HUCITEC, 1995. p. 110-127.

BAHKTIN Mikhail (VOLOCHÍNOV, V.N.). Estética da criação verbal. Traducao Maria Ermantina G. G. Pereira. 2. ed. São Paulo: Martins Fontes, 1997. p. 279325.

BORTONI-RICARDO, Stella Maris; MACHADO, Veruska Ribeiro. (Org.). Os doze trabalhos de Hércules: do oral para o escrito. São Paulo: Parábola, 2013.

BORTONI-RICARDO, Stella Maris; ROCHA, Maria do Rosário. O ensino de português e a variação linguística em sala de aula. In: MARTINS, Marco A. ; VIEIRA, Silvia R.;TAVARES, Maria A. (Org.). Ensino de Português e Sociolinguística. São Paulo: Contexto, 2014. p. 38-55.

BORTONI-RICARDO, Stella Maris. Educação em língua materna: a sociolinguística em sala de aula. São Paulo: Parábola Editorial, 2004. 
BRAIT, Beth. Mikhail Bakhtin: o discurso na vida e o discurso na arte. In: DIETZSCH, Mary Júlia. (Org.). Espaços da linguagem na educação. São Paulo: Humanitas, 1999. v. 1, p. 11-39.

BRANDÃO, Helena H. Nagamine. Gêneros do discurso na escola: mito, cordel, discurso político, divulgação científica. São Paulo: Cortez, 2000.

BRASIL. Secretaria de Educação Fundamental. Parâmetros curriculares nacionais: terceiro e quarto ciclos do ensino fundamental: língua portuguesa. Brasília, 1998.

BRONCKART, Jean-Paul. Atividade de linguagem, textos e discursos: por um interacionismo sócio-discursivo. São Paulo: EDUC, 2003.

CAMPOS, Maria Teresa R. A. et al. Projeto Athos: língua portuguesa, 70 ano. São Paulo: FTD, 2014.

EVARISTO, Marcela Cristina. O cordel em sala de aula. In: BRANDÃO, H. N. Gêneros do discurso na escola: mito, cordel, discurso político, divulgação científica. São Paulo: Cortez, 2000. p. 119-184.

FARACO, Carlos Alberto; NEGRI, Lígia. O falante: que bicho c esse, afinal? Letras, Curitiba, n. 49, p. 171-180. 1998.

CHAMBERS, Jack K; TRUDGILL, Peter. La Dialectología. Tradução Carmén Morán González. Madrid: Visor Libros, 1994.

LABOV, William. Padrões sociolingüísticos. Tradução Marcos Bagno, Maria Marta Scherre e Caroline Cardoso. São Paulo: Parábola, 2008.

LAMBERT, William W.; LAMBERT, Wallace E. Psicologia social. Tradução Álvaro Cabral. 3. ed. Rio de Janeiro: Zahar, 1972.

MACHADO, Irene. Gêneros discursivos. In: BRAIT, Beth (Org.). Bakhtin conceitos-chave. São Paulo: Editora Contexto, 2005. p. 151-166.

MARTINS, Marco A.; VIEIRA, Silvia R.; TAVARES, Maria A. Contribuições da Sociolinguística brasileira para o ensino de português. In: MARTINS, Marco A.; VIEIRA, Silvia R.; TAVARES, Maria A. (Org.). Ensino de Português e Sociolinguística. São Paulo: Contexto, 2014. p. 11-35.

NASCIMENTO, Elvira Lopes. Debate na sala de aula: gênero catalizador para aprendizagens e desenvolvimento. In: BUENO, Luiza; COSTA-HÜBES, Terezinha 
da Conceição (Org.). Gêneros orais no ensino. São Paulo: Mercado de Letras, 2015. p. 206-237.

ROJO, Roxane. Gêneros de discurso/texto como objeto de ensino de língua: um retorno ao trivium? In: SIGNORINI, Inês (Org.). [Re]discutir texto, gênero e discurso. São Paulo: Parábola Editorial, 2008. p. 73-103.

SEVERO, Cristine Gorski. Entre a sociolinguística e os estudos discursivos: o problema da avaliação. Interdisciplinas: Revista de Estudos em Língua e Literatura, Aracajú, Ano 6, V.14, p. 7-15, jul-dez., 2011. 